\title{
Central European Border Settlements and Interwar Ireland: a Transnational Study of the North- Eastern Boundary Bureau and the Boundary Commission
}

\section{IZVLEČEK}

DOGOVORI O SREDNJEEVROPSKIH MEJAH IN IRSKA V OBDOBJU MED VOJNAMA:TRANSNACIONALNA ŠTUDIJA URADA ZA SEVEROVZHODNO MEJO IN MEJNE KOMISIJE

Po koncu prve svetovne vojne so irski nacionalistični krogi zaradi možne delitve Irske zavzeto spremljali rojstvo novih malih neodvisnih držav v vzhodni Srednji Evropi. Iz časopisnih uvodnikov in člankov ter diplomatskih poročil je razvidno, da se je povojna Irska odkrito zanimala za urejanje meja v celinski Evropi, saj je bil razpad Avstro-Ogrske podobno sporen. Namen tega prispevka je raziskati, kako so takratni irski poročevalci dojemali vprašanje urejanja mej v Srednji Evropi, sčimer omogoča vpogled v preoblikovanje političnega prostora na Irskem in $v$ Srednji Evropi. Po kratki predstavitvi ozadja vprašanja irskih meja se prispevek dotakne najpomembnejših točk v zgodovinopisju, povezanih $z$ urejanjem meja v obdobju po prvi svetovni vojni. Podrobno obravnava tudi zgodovino delitve Irske, pri čemer se osredotoča predvsem na Urad za severovzhodno mejo (NorthEastern Boundary Bureau) in Mejno komisijo (Boundary Commission) ter na pomen srednjeevropskih precedensov za njuno delo. Prispevek omogoča tudi vpogled virsko zanimanje za manjšinsko problematiko v evropskih obmejnih regijah po letu 1925 , da bi prikazal navzven usmerjen odnos irskih nacionalistov, celo v zveziz mejami in manjšinami.

Ključne besede: irska meja, plebisciti, transnacionalna zgodovina, Srednja Evropa, delitev

* PhD, National University of Ireland, Galway University Road, Galway, Ireland; 1.zach 1@nuigalway.ie 


\section{ABSTRACT}

In the aftermath of the Great War, the birth of new independent small states in East-Central Europe was closely followed in Irish nationalist circles due to the possibility of Partition in Ireland. Newspaper editorials, journal articles and diplomatic accounts illustrate that post-war Ireland had an open attitude toward the settlement of borders on the Continent as the dissolution of the Austro-Hungarian Empire was similarly controversial. This paper aims to investigate how contemporary Irish commentators perceived the question of boundary settlements in Central Europe in order to provide an insight into the transformation of political space in both Ireland and Central Europe. After providing a brief background to the Irish boundary question, this paper touches upon the most important points in historiography with regard to border settlements in the post-World War I era.. It also discusses Irish Partition history in detail, concentrating on the North-Eastern Boundary Bureau (NEBB) and the Boundary Commission, and the importance of Central European precedents in their work. Moreover, this paper also proposes to provide an insight into the Irish interest in the minority problem in European borderland regions after 1925 in order to illustrate the outward-looking attitude to Irish nationalists, even in relation to borders and minorities.

Keywords: Irish border, plebiscites, transnational history, Central Europe, Partition

\section{Introduction}

The period from 1919 to 1922 saw the transformation of political order in Ireland, while the right to self-determination and independence remained in the centre of Irish political rhetoric. With the outbreak of the Irish War of Independence and the opening of the Fist Dáil Éireann in January 1919, the relationship between Ireland and Britain deteriorated. Political changes in Ireland were accompanied by personnel changes in the informal Irish diplomatic service; "roaming" Sinn Féin envoys were entrusted with disseminating propaganda on the Continent and gaining recognition for the independent Irish republic. After the signing of the Anglo-Irish Treaty in December 1921, due to opposition to the oath of allegiance required of Dáil members and provisions for ongoing links with Britain, a spilt occurred in the Irish republican movement. The Irish Free State, separate from Northern Ireland (established by the Government of Ireland Act, 1920), was a dominion within the British Empire, with legislative independence. The Treaty only provided a partial achievement and a full Republic was only declared decades later, gaining full formal sovereignty for twentysix counties in $1949 .^{1}$

1 Robert Lynch, Revolutionary Ireland, 1912-25 (London: Bloomsbury Academic, 2015), 1. Stephen Howe, Ireland and Empire: Colonial Legacies in Irish History and Culture (Oxford: Oxford University Press, 2000), 41. 
The creation of a Boundary Commission was decided in order to amend the border between the Free State and Northern Ireland, as part of Article 12 in the Treaty: the final border was to be determined "in accordance with the wishes of the inhabitants, so far as may be compatible with economic and geographic conditions [... .". As Paul Murray highlighted, the year the Government of Ireland Act partitioned Ireland, territories in other parts of Europe were also being partitioned. They were assigned to the states that laid claim to them as a result of the post-war treaties that radically redrew of the map of Europe. ${ }^{3}$ Therefore, this controversy in relation to boundaries prompted an open attitude toward similar precedents on the Continent as the dissolution of the Austro-Hungarian Empire also left border disputes. ${ }^{4}$ This paper aims to highlight the significance of Central European border settlements in Irish political discourse with the purpose of illustrating that looking beyond national borders was not irreconcilable with Irish nationalism; on the contrary.

\section{Irish Perceptions of Borders in East-Central Europe After 1918}

The last few months of 1918 saw the complete transformation of the multi-cultural Habsburg Central Europe, from a Dual Monarchy into a number of independent small states. Stephen Howe has argued that the struggle for Irish independence was comparable to Czechoslovakia and Hungary "attaining independence from alien rule". 5 Furthermore, he has also claimed that comparing "experiences of conflict, secession and redrawing of boundaries across Europe and beyond" was worth investigating. ${ }^{6}$

The socio-political changes that resulted from the redefined borders in Europe after the Great War were inseparable from the formulation of national identities across Europe. Although the circumstances were different in Ireland and in Central Europe, the question of border revisions in the Danube basin sparked the interest of Irish contemporaries. When historian Patrick Keatinge described Ireland as "a revisionist small state, both in respect of the constitutional relationship with Britain and of partition [that] gave added edge to the Irish attitude of anti-imperialism in the nineteen-twenties and thirties", he identified common ground between Ireland and other small states in Central Europe based on the revision of treaties (the Anglo-Irish

2 NAI DE 2/304/1, Documents on Irish Foreign Policy [henceforth: DIFP] vol. ii. No. 214, Final text of the Articles of Agreement for a Treaty between Great Britain and Ireland as signed, London, December 6, 1921.

3 Paul Murray, The Irish Boundary Commission and its Origins 1886-1925 (Dublin: UCD Press, 2011), 146.

4 The name of the state had changed on three occasions; between 16 November 1918 and 21 March 1919 it was called 'Hungarian People's Republic' under the leadership of Mihály Károlyi; the 'Hungarian Soviet Republic' was in existence under Béla Kun between 22 March and 2 August 1919; this was followed by the short-lived 'Hungarian People's Republic', August 1919-February 1920. Then in February 1920, the monarchy (Hungarian Kingdom) was restored, without electing a King but with Admiral Miklós Horthy serving as Governor.

5 Howe, Ireland and Empire, 232.

6 Ibid., 237. 
Treaty and the Versailles Peace Treaties, respectively). ${ }^{7}$ Correspondingly, in more recent historiography, Michael Kennedy has confirmed that interwar Ireland "was siding with the 'revisionist states', urging the revision of the post-war Paris Peace Treaties and constructing Irish foreign policy as part of the post-Versailles world order. $^{8}$

From the end of October 1918, the Irish press provided much coverage of how the Austrian empire was broken up. The Irish dailies were aware of the fact that the now powerless Austrian Government could not stand in the way of Polish, Hungarian, Czechoslovak and Yugoslav independence. ${ }^{9}$ By 2 November 1918, the Irish Independent announced: "the disintegration of the Austrian Empire [might] be said to be complete," 10 granting the independence of northern and southern Slavic people was a touchy subject for Irish nationalists, as their pleas for the same goal were rejected by the great powers late 1918/early 1919. The establishment of an Austrian republic was also noticed in Irish journals and newspapers due to the state's overwhelmingly Catholic traditions. In addition, Irish interest was apparent in articles regarding the political turmoil in independent Hungary as well.

J. J. Lee, who has compared Irish socio-economic and political developments with the case of other small states in his book Ireland 1912-1985 (1990), has also pointed out the differences between post-war border disputes in Ireland and Central Europe. Lee has emphasised that after the Great War "borders were revised in central and eastern Europe in favour of smaller states. This was precisely what did not happen in Fermanagh and Tyrone." Interestingly, Lee has also argued that "the Free State enjoyed yet a further advantage. It was not the potential victim of irredentist or imperialist ambitions", unlike East-Central European states. ${ }^{12}$ And while the Irish Free State had no Banat, no Silesia, no Slovakia, and no Transylvania, Northern Ireland was still the object of irredentist nationalist claims. ${ }^{13}$ Therefore, irredentism was a key factor in the context of border-related conflicts, both in Ireland and in the successor states. Joep Leerssen has explained this with the fact that irredentism seemed to be the "logical and almost unavoidable extension" of nationalism in post-war Europe. ${ }^{14}$ Similarly, Paul Murray, in a major study of the Irish Boundary Commission, compared the claims of Irish nationalists and Central European irredentists. He concluded that since the 1801 Act of Union was still in effect, in partitioning Ireland, “... the British legislature was establishing a new boundary within part of the United Kingdom

7 Patrick Keatinge, A Place among the Nations: Issues of Irish Foreign Policy (Dublin: Institute of Public Administration, 1978), 172.

8 Michael Kennedy, "Chicanery and Candour: The Irish Free State and the Geneva Protocol, 1924-5," Irish Historical Studies vol. xxix, No. 115 (May 1995), 377 and 383.

9 "Austrian Empire Broken Up. Emperor's Manifesto. Four Separate States Decreed," Irish Independent, October 18, 1918. "Break-Up of Austria," Freeman's Journal, October 18, 1918.

10 "Austria's Complete Break Up. Vienna-Budapest Revolutions. Count Tisza Killed. Bosnia Joins Serbia: New AustroGerman State. Fleet Given to Jugo-Slavs," Irish Independent, November 2, 1918.

11 J. J. Lee, Ireland 1912-1985: Politics and Society (Cambridge: Cambridge University Press, 1989), 46.

12 Ibid., 78, 79.

13 Ibid.

14 Joep Leerssen, National Thought in Europe: A Cultural History (Amsterdam: Amsterdam University Press, 2008), 176. 
over which it exercised the same political control as it did over the other parts. The boundary settlements in Central and Eastern Europe, in contrast, were the result of external interference with the territorial integrity of states which found themselves on the losing side in the First World War." ${ }^{15}$

\section{Partition History: the North-East Boundary Bureau and the Boundary Commission}

As it has been established in the Introduction, the struggle between unionists and nationalists over the Home Rule question had been part of political debates before the Great War. However, it was the Government of Ireland Act of 1920 that eventually sought to create two states, Northern Ireland and Southern Ireland, and establish two parliaments (the southern parliament envisaged did not materialise and Home Rule, which was granted to both, took effect only in the north). ${ }^{16}$ The Anglo-Irish Treaty of 1921 brought further legislation to settle the relationship, allowing the recently formed state of Northern Ireland to opt out of the Irish Free State. In the case of the latter, a Boundary Commission would be established to amend the (presently provisional) border between Northern Ireland (still part of the United Kingdom) and the Irish Free State (gained dominion status). The "Provisional-Government-sponsored" North-Eastern Boundary Bureau (NEBB - October 1922) and then the Boundary Commission (first met in November 1924) were to make a decision "in accordance with the wishes of the inhabitants, so far as may be compatible with economic and geographic conditions. ${ }^{17}$ First and foremost, before discussing the cases of European boundary commissions, the Memorandum on the European Precedents for the NEBB declared that: "it must be remembered that in Ireland a boundary has already been drawn through the disputed areas, such as did not exist in Europe. It seems plain that the wishes of the inhabitants on both sides of it are to be taken into account."18

In order to support their claim with successful precedents, the NEBB investigated similar boundary settlements in post-war Europe. Director Kevin O'Shiel, researcher Bolton C. Waller, secretary Edward Millington Stephens were those most involved in the process. ${ }^{19}$ O'Shiel requested Waller, an expert on European boundary disputes to advise him. Waller, who was in charge of researching international precedents fulltime in London, argued that in Ireland a plebiscite was simply unnecessary due to the fact that the wishes of the inhabitants were well known as a result of the elections,

15 Paul Murray, The Irish Boundary Commission and its Origins 1886-1925 (Dublin: UCD Press, 2011), 299.

16 Ged Martin, “The Origins of Partition," in: The Irish Border: History, Politics, Culture, eds. Malcolm Anderson and Eberhard Bort (Liverpool: Liverpool University Press, 1999), 67.

17 Michael Kennedy, Division and Consensus: The Politics of Cross-Border Relations in Ireland 1925-1969 (Dublin: Institute of Public Administration, 2000), 9. Geoffrey J. Hand, "Introduction," in: Report of the Irish Boundary Commission 1925 (Shannon: Irish University Press, 1969), viii.

UCDA P35b/132 (28), Patrick McGilligan Papers, Memorandum on the European Precedents for the North Eastern Boundary Bureau.

19 Eda Sagarra, Kevin O'Shiel: Tyrone Nationalist and Irish State-Builder (Dublin: Irish Academic Press, 2013), $201-04$. 
stressing that "the expense and possible danger of a plebiscite are best avoided." ${ }^{20} \mathrm{E}$. M. Stephens, barrister and civil servant, was also required to study "recent European precedents for territorial transfer on the basis of local plebiscites", and to collect data and to intermediate between the Dublin government and nationalist officials in the border areas. ${ }^{21}$ Moreover, the Irish trade representative in Berlin at the time, Charles Bewley (later minister to Germany 1933-1939), also furnished the Bureau "with certain particulars regarding Boundary Commissions on the Continent." 22 In particular, Bewley sent reports on the Upper Silesian plebiscite conditions and the Schleswig Commission.

Historian Paul Murray has highlighted the fact that the Bureau had found the plebiscites of the following territories noteworthy: Upper Silesia (March 1921) between Poland and Germany; Schleswig (February-March 1920) between Denmark and Germany, and Klagenfurt/Celovec in south-eastern Carinthia (October 1920) between Austria and the Kingdom of the Serbs, Croats and Slovenes, in addition to the general border question in Hungary. ${ }^{23}$ In these areas, plebiscites, impartially conducted and supervised, were employed as the means of ascertaining the wishes of inhabitants with a view to assigning them to the jurisdiction of their choice.

As far as the border between Austria and Hungary was concerned, Austria successfully claimed Western Hungary (Burgenland, with the exception of Sopron/ Oedenburg), and was permitted to occupy these territories on 7 August 1921. In the city of Sopron/Oedenburg a plebiscite (December 1921) decided in favour of staying under the Hungarian state. The plebiscite was attacked by many (nonMagyar) contemporaries, and was later questioned by historians. Throughout the conflict, the Irish press, relying on Reuters cablegrams from Berlin and telegrams from Vienna, echoed the Austrian opinion. ${ }^{24}$ Interestingly, there were no references to this particular precedent in the records of the NEBB or the Boundary Commission, despite the large publicity the events attracted in the Irish papers.

20 Ibid. UCDA P35b/133, North-Eastern Boundary Bureau Final Report, 26 February 1926, by E. M. Stephens, Secretary. UCDA LA1/H/83, Eoin MacNeill Papers, Confidential Memorandum by Kevin O'Shiel entitled "Procedure at Boundary Commission”, 1922. UCDA LA1/H/95, Eoin MacNeill Papers, Memorandum by Kevin O’Shiel with covering letter relating to political relations between the Irish Free State and the Irish North-Eastern minority, June 1923. UCDA LA1/H/83, Eoin MacNeill Papers, Kevin O'Shiel - "Boundary Commission and its precedents". UCDA LA1/H/89, Eoin MacNeill Papers, Notes on Procedure of Boundary Commission.

21 NAI DT S4743, DIFP vol. ii, No. 380, Final Report of the North-Eastern Boundary Bureau, E.M. Stephens to Kevin O’Higgins (Dublin), 26 February 1926, accessed September 23, 2015, http://www.difp.ie/docs/1926/Work-ofthe-North-Eastern-Boundary-Bureau/716.htm. Andrew Carpenter and Lawrence William White, "Stephens, Edward Millington," Dictionary of Irish Biography [henceforth: DIB], accessed August 7, 2015, http://dib.cambridge. org/viewReadPage.do?articleId=a8276.

22 NAI FIN/1/2168, National Archives of Ireland, Department of Finance Files, Letter from E. M. Stephens, Secretary of the NEBB to the Secretary, Department of Finance, 26 January 1923.

23 Murray, The Irish Boundary Commission, 146, 241 and 247.

24 "Just another War Front. Hungarians Invade Austria," Irish Independent, September 7, 1921. "Burgenland Plebiscite. Budapest Claims Big Majority for Hungary in Oedenburg," Freeman's Journal, December 19, 1921. "Austrian Objections. Report that Oedenburg is to Go to Hungary Brings Protest," Freeman's Journal, December 28, 1921. Jeremy King, "Austria vs. Hungary: Nationhood, Statehood, and Violence since 1867," in: Nationalitätenkonflikte im 20. Jahrhundert: Ursachen von inter ethnischer Gewalt im europäischen Vergleich [Nationality Conflicts in the $20^{\text {th }}$ Century: Causes of Inter-Ethnic Violence in European Comparison], eds. Philipp Ther and Holm Sundhaussen (Berlin: Harrassowitz, 2001), 174, 175. 
In the registry of NEBB documents, there was only one reference to Hungarian borders in this context. The file compiled in relation to the northern Hungarian border and the question of the Ruthenian minority was actually a copy of the Czechoslovak memorandum presented at the Paris Peace Conference. Therefore, it reflected the arguments of the Czechoslovak Republic, claiming the territory inhabited by Ruthenians in the north-eastern part of the former Dual Monarchy. The Czechoslovak memorandum stressed that: "the Ruthenians of Hungary, a nation closely related to the Slovaks, live under the same conditions as the Slovaks, that they are in very intimate relation with them, that their union to the Czecho-Slovak Republic would cause no difficulty whatever. 2 . This solution would best respond to the political reality and to the principles of justice."2s

Similarly, other NEBB documents regarding continental precedents such as territorial disputes about the Carinthian Klagenfurt/Celovec area between Austria and Yugoslavia (in favour of Slovene claims as opposed to the demands of the German population), the case of the Bohemian Germans or the general territorial demands of Czechoslovakia were based on the Czech and Yugoslav memoranda, respectively, and presented at Versailles. ${ }^{26}$ In consequence, when it came to Irish claims in relation to the north-eastern boundary, there were very few references to Austrian or Hungarian examples, despite the high number of incidents (including the occasional plebiscites) there. Nevertheless, Eda Sagarra has pointed out that the phrasing of Article 12 of the Anglo-Irish Treaty and its interpretation by the Free State is "to be understood in the context of the plebiscitary politics of post-war Central Europe, notably as laid down in the Treaties of Versailles and Trianon", referring to Upper Silesia, Klagenfurt, Burgenland, North Schleswig, and East Prussia. ${ }^{27}$ As the Austro-Hungarian Empire was defeated in the Great War, their successors' claims were treated differently by the great powers at and after Versailles than the victorious, newly independent small nations in the region. Therefore, when the Irish commission was looking for a precedent to support Irish nationalist demands, they rather examined the appeals of previously successful small states. Altogether, the very fact that the question of boundaries was in dispute created a greater Irish interest in territorial settlements in Europe.

In post-war Europe, there was no guarantee that the political boundaries were about to reflect ethnic boundaries; indeed, when it came to the boundary issue in Ireland, eventually, no plebiscite was held, despite the research done by the NEBB and the personal experience of, for instance, F. B. Bourdillon, Secretary of Irish Boundary Commission, former member of the Upper Silesian Commission

25 NAI NEBB/2/1/13, Peace Conference. Czecho-Slovak Delegation, memo No. 6. Problem of the Ruthenians of Hungary. Peace Conference Documents. Czecho-Slovak Delegation.

26 Ibid. NAI NEBB/2/1/12, Peace Conference Document. Jugo-Slav Delegation. The Problem of Celovec (Klagenfurth). NAI NEBB/2/1/10, Peace Conference Documents. Czecho-Slovak Delegation. Problem Touching the Germans in Bohemia. NAI NEBB/2/1/11, The Territorial Claims of the Czecho-Slovak Republic. Peace Conference Document. Czecho-Slovak Delegation. Memoire No. 2. UCDA P35b/132(28), Patrick McGilligan Papers, Memorandum on the European Precedents for the North Eastern Boundary Bureau. 
(1920-22). ${ }^{28}$ Bourdillon's interest in the boundary situation on the Continent was well documented; in his letter to E. M. Stephens, dated 15 October 1924, the Irish publicity agent of the Bureau, Hugh A. McCartan, emphasised that Bourdillon "was much interested in the Upper Silesian precedent." ${ }^{29}$

During the interwar years, the possibility of treaty revisions was a frequently discussed topic across Europe, including in Ireland. It was visible that "the Treaty of Versailles was not a heaven-sent document, to be regarded forever as rigid and inviolable. On the contrary," argued the Irish Press; "it was - like the 'Treaty' forced on us - a settlement based on compulsion and an attempt to perpetuate the spoils system in its delimitation of frontiers." ${ }^{30}$ Echoing de Valera's agenda and ideas about "peaceful revision”, placing the Irish question in parallel with other European small nations, the paper claimed: "...We in Ireland have more than an academic interest in this question. Ireland is one of the small nations which for centuries has endured oppression at the hands of powerful neighbouring State. [...] Revision and readjustment must come, if there is to be lasting peace in the world [... . There must be provision for changing international treaties or conditions that bear within themselves the seeds of future wars." 31

Therefore, Irish newspapers regularly pointed to the Versailles treaties when discussing the prevailing "minorities question" in Central Europe, in parallel with the legacy of the Irish border settlement. The Free State's disappointment with regards the Boundary Commission was undeniable; eventually the existing borders were confirmed on December 3, 1925, after the British Conservative Morning Post leaked the planned transfers on November 7, 1925. The report of the Boundary Commission was suppressed and not published until 1969.

\section{Irish Interest in the Minority Problem in Borderland Regions After 1925}

The Irish dissatisfaction with the borders in the early 1920s resulted in an active participation in the League of Nations, which was expected to see to the protection of, among others, the northern Irish Catholic minority. This was crucial for the Free State under both Cumann na nGaedheal's William T. Cosgrave and Fianna Fáil's Eamon de Valera (after 1932). Interestingly, although during the interwar years the Irish External Affairs took a close interest in minority problems at Geneva, at the same time, the Department was also keen on adhering to a non-partitionist attitude in relation to Ireland..$^{32}$

28 NAI NEBB/4/5/2, Copy of Letter from Hugh A. McCartan to Stephens, 15 October 1924.

29 Ibid.

30 “Europe’s Problems," Irish Press, September 26, 1935.

31 Ibid.

32 Gerard Keown, “Creating an Irish Foreign Policy in the 1930s," in: Irish Foreign Policy 1919-1966: From Independence to Internationalism, eds. Michael Kennedy and Joseph Morrison Skelly (Dublin: Four Courts Press, 2000), 38. 
Rogers Brubaker has noted that borderland conflicts in Central Europe after the Great War became "internationalised" ${ }^{33}$ For small states, like the Irish Free State, a crucial aspect of League of Nations membership was the organisation's declared role as protecting ethnic and religious minorities. Therefore, when expecting the support of other small nations, it was not surprising when diplomats like the Irish High Commissioner in London (5 February 1929-14 December 1930), Timothy Smiddy, articulated the view that the Irish Free State could be regarded as "a champion of the national interests of small States, as also of minorities". ${ }^{34}$

Between the two world wars, the problematic nature of the boundary question was also highlighted by the aforementioned Bolton C. Waller. In addition to his role as researcher in the NEBB, Waller was also involved in the application procedure of the Free State's admission to the League. He took note of the fact that simultaneous requests were made by Iceland, Latvia, Finland, Lithuania and Hungary as well. ${ }^{35}$ Later he became the President of the League of Nations Society of Ireland..$^{36}$ In his writings, Waller focused on the role of the League in keeping up peace and suggested, among others, to implement "improved safeguards for minorities." ${ }^{37}$ As early as 1922-1923, he claimed that certain segments of the Versailles treaties that redrew boundaries across Europe could be adopted in relation to the Irish boundary as well. ${ }^{38}$ Writing in 1925, he argued that it was unworthy of Ireland as a small nation and "out of accord with our traditions and temperament, being as we are a roaming and restless people," to avoid "all entanglements with the rest of the world." ${ }^{39}$ He explained this with the fact that "throughout our history we have been concerned with the spread of ideas, and have had an influence out of all proportion to our size or strength." ${ }^{40}$ Therefore, argued Waller, the League provided the best opportunity for small nations like Ireland to play a part in the world. ${ }^{41}$

One of the main tasks of the League, Waller found, was to supervise the protection of minority rights. ${ }^{42}$ This proved to be problematic, as demonstrated by his article of

33 Rogers Brubaker, Nationalist Politics and Everyday Ethnicity in a Transylvanian Town (Princeton: Princeton University Press, 2006), 49.

34 Michael Kennedy, "Smiddy, Timothy Anthony," DIB, accessed December 16, 2014, http://dib.cambridge.org/ viewReadPage.do?articleId=a8130. Aengus Nolan, Joseph Walshe: Irish Foreign Policy 1922-1946 (Cork: Mercier Press, 2008), 38 .

35 UCDA LA1/H/61, Eoin MacNeill Papers, Typescript report by B.C. Waller on the application of the Irish Free State for admission to the League of Nations. Bolton C. Waller, Ireland and the League of Nations (Dublin: Talbot Press, 1925). Bolton C. Waller, Paths to World Peace (London: G. Allen \& Unwin, 1926). Bolton C. Waller, Hibernia, or, The Future of Ireland (London: Dutton, 1928).

36 Michael Kennedy, Ireland and the League of Nations 1919-1946. International Relations, Diplomacy and Politics (Dublin: Irish Academic Press, 1996), 28.

37 “European Peace. Irishman's Prize Essay," Irish Independent, September 16, 1924. NAI DT S4084, DIFP vol. ii, No. 272, Kevin O'Higgins to each member of the Executive Council, enclosing a memorandum on the Boundary Question (C.1987/24) (Confidential), Dublin, 25 September 1924, accessed September 23, 2015, http://www.difp.ie/ docs/1924/Boundary-Commission:-possible-offer-to-Northern-Ireland/608.htm.

38 UCDA LA1/H/89, Eoin MacNeill Papers, Typescript memorandum by B.C. Waller on "European precedents for the North-Eastern Boundary Bureau," 1922-1923.

39 Waller, Ireland and the League of Nations, 18.

40 Ibid.

41 Ibid., 66.

42 Ibid., 37. 
March 1929 in the Irish Independent, where Waller declared that the Council faced its "least successful" challenge up to date; dealing with the "complaints and petitions" of certain "aggrieved minorities" including Finland, Romania, Hungary, and the German minority in Upper Silesia. ${ }^{43}$ "The problem of minorities in Europe is real and threatening", emphasised Waller, most likely leading to war. ${ }^{44}$ The Cork Examiner named a possible reason for the negligence of the question to be the fact that "very few older members of the League could honestly declare that they themselves invariably treated their minorities in accordance with the spirit of the guaranteeing Treaty." ${ }^{45}$ Indeed, the ethno-linguistic and religious divisions, such as the cases observed by the Cork Examiner, were so deeply embedded in certain societies that the presence of the League of could not remedy the situation. ${ }^{46}$

Irish perceptions of the regional minorities in the borderlands, "outside the imagined" newly independent nation-states, illustrate the complexity of Central European identities in the face of extreme political changes. ${ }^{47}$ The troubling nature of minority issues was frequently discussed in the Irish press in the interwar years. This was visible, among others, in Irish comments on the Sudeten Germans in the Czechoslovak State; the formerly Austrian Catholics in the South Tyrol; and Hungarians along the frontiers of Czechoslovakia, Romania and Yugoslavia.

\section{Conclusion}

The importance of Central European precedents within the context of Irish partition and boundary settlement sheds light on a lesser discussed part of Irish nationalist discourse, namely, the outward looking attitude Irish nationalists had in relation to Partition. Therefore, this paper hoped to highlight the significance of the wider international context when investigating the Irish border question in the early interwar years. It aimed to illustrate Irish awareness of the political transformation of Central Europe and territorial settlements after the Great War, with special attention the plebiscites in Upper Silesia and Klagenfurt, also emphasising the significance the League of Nations, particularly after the failure of the Boundary Commission. Consequently, even though the Boundary Commission failed to alter the Irish border, the history of its work should be viewed as part of a larger European narrative.

43 “Dangers that Threaten World Peace," Irish Independent, March 6, 1929.

44 Ibid.

45 “Protection of Minorities," Cork Examiner, July 3, 1930.

46 Zara Steiner, The Lights That Failed. European International History 1919-1933 (Oxford: Oxford University Press, 2007), 364.

47 Brubaker, Nationalist Politics, 46. 


\section{Sources and Literature}

\section{Archive Sources:}

- NAI, National Archives of Ireland:

- Department of Finance Files - FIN/1/2168.

- North-Eastern Boundary Bureau Files, NEBB/2/1/10, NEBB/2/1/11, NEBB/2/1/12, $\mathrm{NEBB} / 2 / 1 / 13, \mathrm{NEBB} / 4 / 5 / 2$.

- UCDA, University College Dublin Archives:

- Eoin MacNeill Papers, LA1/H/61, LA1/H/83, LA1/H/89, LA1/H/95.

- Patrick McGilligan Papers, P35b/132 (28), P35b/133.

\section{Archive Sources (Online):}

- NAI DE 2/304/1, National Archives of Ireland, Dáil Éireann Files, Documents on Irish Foreign Policy [DIFP] vol. ii. No. 214, Final text of the Articles of Agreement for a Treaty between Great Britain and Ireland as signed (London), December 6, 1921. Accessed September 23, 2015. http:// www.difp.ie/docs/1921/Anglo-Irish-Treaty/214.htm.

- NAI DT S4084, National Archives of Ireland, Department of the Taoiseach Files, Documents on Irish Foreign Policy [DIFP] vol. ii, No. 272, Kevin O'Higgins to each member of the Executive Council, enclosing a memorandum on the Boundary Question (C.1987/24) (Confidential), Dublin, 25 September 1924. Accessed September 23, 2015. http://www.difp.ie/docs/1924/ Boundary-Commission:-possible-offer-to-Northern-Ireland/608.htm.

- NAI DT S4743, National Archives of Ireland, Department of the Taoiseach Files, Documents on Irish Foreign Policy [DIFP] vol. ii, No. 380, Final Report of the North-Eastern Boundary Bureau, E.M. Stephens to Kevin O’Higgins (Dublin), 26 February 1926. Accessed September 23, 2015. http://www.difp.ie/docs/1926/Work-of-the-North-Eastern-Boundary-Bureau/716.htm.

\section{Literature:}

- Brubaker, Rogers. Nationalist Politics and Everyday Ethnicity in a Transylvanian Town. Princeton: Princeton University Press, 2006.

- Hand, Geoffrey J. "Introduction." In: Report of the Irish Boundary Commission 1925. Shannon: Irish University Press, 1969.

- Howe, Stephen. Ireland and Empire: Colonial Legacies in Irish History and Culture. Oxford: Oxford University Press, 2000.

- Keatinge, Patrick. A Place among the Nations: Issues of Irish Foreign Policy. Dublin: Institute of Public Administration, 1978.

- Kennedy, Michael. "Chicanery and Candour: The Irish Free State and the Geneva Protocol, 19245." Irish Historical Studies vol. xxix, No. 115 (May 1995): 371-84.

- Kennedy, Michael. Division and Consensus: The Politics of Cross-Border Relations in Ireland 19251969. Dublin: Institute of Public Administration, 2000.

- Kennedy, Michael. Ireland and the League of Nations 1919-1946. International Relations, Diplomacy and Politics. Dublin: Irish Academic Press, 1996.

- Keown, Gerard. "Creating an Irish Foreign Policy in the 1930s." In: Irish Foreign Policy 1919-1966: From Independence to Internationalism, edited by Michael Kennedy and Joseph Morrison Skelly, 25-43. Dublin: Four Courts Press, 2000. 
- King, Jeremy. "Austria vs. Hungary: Nationhood, Statehood, and Violence since 1867." In: Nationalitätenkonflikte im 20. Jahrhundert: Ursachen von inter ethnischer Gewalt im europäischen Vergleich [Nationality Conflicts in the 20 $0^{\text {th }}$ Century: Causes of Inter-Ethnic Violence in European Comparison], edited by Philipp Ther and Holm Sundhaussen, 163-82. Berlin: Harrassowitz, 2001.

- Lee, J. J. Ireland 1912-1985: Politics and Society. Cambridge: Cambridge University Press, 1989.

- Leerssen, Joep. National Thought in Europe: A Cultural History. Amsterdam: Amsterdam University Press, 2008.

- Lynch, Robert. Revolutionary Ireland, 1912-25. London: Bloomsbury Academic, 2015.

- Martin, Ged. “The Origins of Partition." In: The Irish Border: History, Politics, Culture, edited by Malcolm Anderson and Eberhard Bort, 57-112. Liverpool: Liverpool University Press, 1999.

- Murray, Paul. The Irish Boundary Commission and its Origins 1886-1925. Dublin: UCD Press, 2011.

- Nolan, Aengus. Joseph Walshe: Irish Foreign Policy 1922-1946. Cork: Mercier Press, 2008.

- Sagarra, Eda. Kevin O'Shiel: Tyrone Nationalist and Irish State-Builder. Dublin: Irish Academic Press, 2013.

- Sharp, Alan. "Reflections on the Remaking of Europe 1815, 1919, 1945, post-1989: Some Comparative Reflections." Irish Studies in International Affairs vol. viii (1997): 5-20.

- Steiner, Zara. The Lights That Failed. European International History 1919-1933. Oxford: Oxford University Press, 2007.

\section{Newspaper Sources:}

- Cork Examiner, July 3, 1930. "Protection of Minorities."

- Freeman's Journal, October 18, 1918. "Break-Up of Austria."

- Freeman's Journal, December 19, 1921. "Burgenland Plebiscite. Budapest Claims Big Majority for Hungary in Oedenburg."

- Freeman's Journal, December 28, 1921. "Austrian Objections. Report that Oedenburg is to Go to Hungary Brings Protest."

- Irish Independent, October 18, 1918. "Austrian Empire Broken Up. Emperor's Manifesto. Four Separate States Decreed."

- Irish Independent, November 2, 1918. "Austria’s Complete Break Up. Vienna-Budapest Revolutions. Count Tisza Killed. Bosnia Joins Serbia: New Austro-German State. Fleet Given to Jugo-Slavs."

- Irish Independent, September 7, 1921. "Just another War Front. Hungarians Invade Austria."

- Irish Independent, September 16, 1924. "European Peace. Irishman’s Prize Essay."

- Irish Independent, March 6, 1929. "Dangers that Threaten World Peace."

- Irish Press, September 26, 1935. "Europe’s Problems.”

\section{Online Sources:}

- Carpenter, Andrew and Lawrence William White. "Stephens, Edward Millington." Dictionary of Irish Biography. Accessed August 7, 2015. http://dib.cambridge.org/viewReadPage. do?articleId=a8276.

- Kennedy, Michael. "Smiddy, Timothy Anthony." Dictionary of Irish Biography. Accessed December 16, 2014. http://dib.cambridge.org/viewReadPage.do?articleId=a8130.

\section{Other Sources:}

- Waller, Bolton C. Hibernia, or, The Future of Ireland. London: Dutton, 1928.

- Waller, Bolton C. Ireland and the League of Nations. Dublin: Talbot Press, 1925.

- Waller, Bolton C. Paths to World Peace. London: G. Allen \& Unwin, 1926. 


\section{Lili Zách}

\section{DOGOVORI O SREDNJEEVROPSKIH MEJAH IN IRSKA V OBDOBJU MED VOJNAMA: TRANSNACIONALNA ŠTUDIJA URADA ZA SEVEROVZHODNO MEJO IN MEJNE KOMISIJE}

POVZETEK

Glede na dokumentirano irsko zanimanje za urejanje evropskih meja je namen tega prispevka osvetliti pomen precedensov z ozemlja nekdanje Avstro-Ogrske in njihov vpliv na irsko mejno vprašanje v letih po prvi svetovni vojni. Po podpisu versajskih mirovnih pogodb so bile novozačrtane meje v Srednji Evropi deležne precej pozornosti tudi v irski javnosti in časopisju, ne samo v tamkajšnjih političnih krogih. Prelomni točki v irskem mejnem vprašanju sta predstavljala zakon o vladi Irske (Government of Ireland Act) iz leta 1920, v skladu s katerim naj bi na irskem otoku nastali dve državi, in angleško-irski sporazum (Anglo-Irish Treaty), ki je omogočil novoustanovljeni državi Severni Irski ločitev od Svobodne države Irske. Sčasoma sta bila ustanovljena Urad za severovzhodno mejo (NEBB - oktobra 1922) in pozneje še Mejna komisija (novembra 1924), da bi popravila (prvo začasno) mejo med Severno Irsko in Svobodno državo Irsko v skladu $\mathrm{z} \gg$ željami prebivalcev«.

Za utemeljitev zahtev je Urad za severovzhodno mejo preučil podobne dogovore o mejah v povojni Evropi. Direktor Kevin O’Shiel, raziskovalec Bolton C. Waller in sekretar Edward Millington Stephens so bili ključni akterji pri raziskovanju in odločanju. Poleg tega so bile zelo pomembne tudi osebne izkušnje F. B. Bourdillona, sektretarja Mejne komisije za Irsko, nekdanjega člana Komisije za Gornjo Šlezijo (1920-22), saj je lahko primerjal celinske dogovore z irskimi okoliščinami. Urad za severovzhodno mejo in Mejna komisija sta posvetila precej pozornosti plebiscitom zaradi poudarjenega pomena $\gg$ želj prebivalcev« tudi v irskem primeru. Zato so se Uradu zdeli pomembni plebisciti na naslednjih ozemljih: v Gornji Šleziji (marec 1921); v Schleswigu (februar-marec 1920); in v Celovcu na jugovzhodu avstrijske Koroške (oktober 1920). Kljub temu pa na Irskem ni bilo plebiscita in tudi meja med Severno Irsko in Svobodno državo Irsko se ni spremenila, saj so bile obstoječe meje potrjene 3. decembra 1925, potem ko je britanski časopis Morning Post 7. novembra 1925 razkril načrtovane premike meja. Kljub neuspehu Mejne komisije pa je mogoče ugotoviti, da se vprašanje meja na Irskem ni obravnavalo osamljeno, ampak je bilo del širše evropske zgodbe.

Najpomembnejša posledica Mejne komisije za Irsko je bilo okrepljeno irsko sodelovanje $v$ Društvu narodov glede na vlogo, ki jo je ta organizacija imela $v$ zaščiti etničnih in verskih manjših. Irski nacionalisti so si torej tudi za razpravo o ozemeljskih zahtevah, reviziji in pravicah manjših izbrali širši mednarodni oder, kjer so predstavili svoje zahteve in pogosto razpravljali o drugih dogovorih glede meja na celini. $\mathrm{Na}$ splošno je cilj tega prispevka prikazati, kako se je zgolj zaradi dejstva, da je bilo 
vprašanje meja sporno, povečalo irsko zanimanje za ozemeljske dogovore v Evropi, kar pomeni, da neodvisna Irska ni bila vase zagledana država, za kakršno je veljala pred tem. 